\title{
Institute of taxation and its contribution to economic structure development (Russian practice)
}

\author{
Yu. Vertakova ${ }^{1}, T$. Miroshnikova ${ }^{2}$, and $S$. Zdolnikova $^{3, *}$ \\ ${ }^{1}$ South-West State University, 305040, 50 years of October str., 94, Kursk, the Russian Federation \\ ${ }^{2}$ Vladivostok State University of Economics and Service, 690014, Gogol str., 41, Vladivostok, the Russian Federation \\ ${ }^{3}$ Peter the Great St.Petersburg Polytechnic University, 195251, Polytechnicheskaya str., 29, St.Petersburg, the Russian Federation
}

\begin{abstract}
Improving the quality of operations and controllability of the Federal Tax Service' (hereinafter - FTS) system is very relevant today. The solution of this problem is complicated by the total amount of regions and their large geographical area, as well as the distances between major cities. One of the necessary tools to increase its efficiency is the creation of a new model, which includes automated data transfer system in the data processing centers (hereinafter - DPC). The composition of the function includes: receiving, registering and digitizing (scanning) of paper-based documents; Massive data input from e-based/paper-based to FTS database; mass printing and mailing tax notifications; archiving paper-based documents. The cost effect is achieved thanks to the elimination of non-core functions, diminution of staff due to centralization, reduction of equipment. The result is saving a share of the national budget.
\end{abstract}

\section{Introduction}

The current state of economic climate in Russia shows us that it is very important to analyze a quality of operations of the Federal Tax Service' system. Based on the correlation and regression analysis we can make a decision about a new optimal model of tax system in Russian Federation.

Russia has faced with condition of ineffective operation of the tax system from the point of view of result of the Federal budget. There is a necessity of large-scale changes to create a new economic model which based on the creation of new automated data transfer system in the data processing centers (Ketels K., 2005). According to the results of modeling, cover the entire territory of Russia was defined geographical clusters. Assessment of the economic effects was carried out on the basis of the model developed CMDI activity for 5 years, which includes the production plan, organizational plan and spending plan by major economy CMDI. Modeling activities CMDI based on a combination of formal (mathematical) methods, expert assessments of experts and statistical data. Regardless of the dynamics of volumes of production, the centralization of mass print function will allow you to achieve significant cost savings.

It is a complicated problem in condition of a lack of financial resources in our economy. Thus, a key to the development of the Russian economy is the formation of the new tax service for country budget.

\section{Methodological approach}

Preliminary approach to the procedure includes four directions of work:

Determination of factors influencing on the placement of DPC

Correlation and regression analysis of the current indicators of DPC' performance

$\mathrm{ABC}$ analysis of the current performance of the DPC by main indicators

Positioning of the operational IFTS according different criteria

Correlation and regression analysis performed by consultant with using of statistical modeling of the dynamics of performance indicators of DPC in 7-10 years. Prognosis horizon is set up to 10 years - until 2020.

This analysis is carried out to identify common patterns of change between performance indicators and influencing factors. Predictive model was built on the basis of the factors with high level of correlation.

The task of ABC analysis of DPC' current activities based on main parameters of performance is to determine the individual IFTS or forming regional group for conversion to DPC. The optimal (best) will be to perform an ABC analysis of IFTS in the dynamics of 5-7 years in increments of 2 years. This method is a quantitative and it objectively segregates all IFTS by main indicators on 3 or more segments. The main criteria

* Corresponding author: s.v.zdolnikova@yandex.ru 
for the evaluation of all IFTS is segmented to 3 scales (3 - dimensional coordinate system):

On a scale of «A-B-C» - the IFTS segmented by Criterion 1.

On a scale of «X-Y-Z» - the IFTS segmented by Criterion 2.

On a scale of «L-M-N» - the IFTS segmented by Criterion 3.

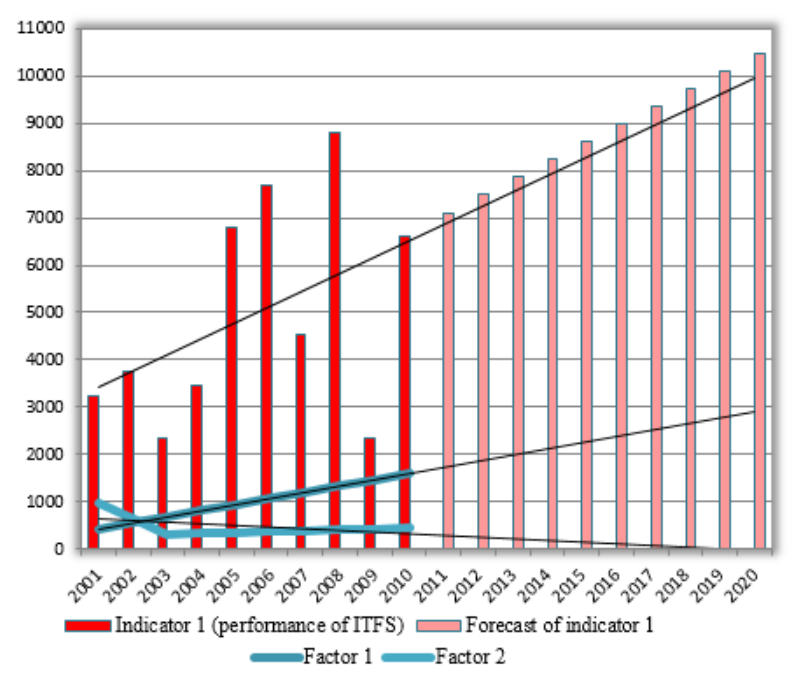

Fig. 1. Correlation and regression analysis according different criteria.

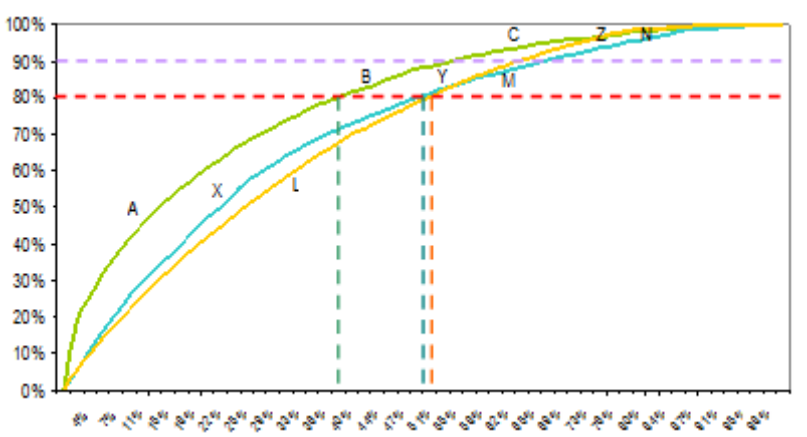

Fig. 2. ABC analysis of DPC' current activities.

After a segmentation of the IFTS analyzed indicators into 3 groups performed cross-analysis, and depending on the number of analyzed indicators and factors of influence can be formed into a targeted IFTS clusters.

The analysis of socio-economic situation of regions was performed by analytical processing on following criteria: the Volume of the GRP (Gross Regional Product); average monthly wages; the amount of companies and organizations; the amount of small businesses; population; population density. As part of the transport infrastructure of the regions were analyzed:

\section{Density of roads}

The number of post offices

After analysis of each indicator was compiled overall rating of regions and selected the most relevant of them. Further, based on the analysis of environmental data and performance indicators directly to the IFTS by regions defined target regions for accommodation of the new data centers (mass data input centers).
The next step was trends' forming and IFTS positioning:

In total number of stuff listed factors may be other factors such as: costs (labor, maintenance, etc.); Transport leg; Number of taxpayers; Sectoral specialization of regions of Russia; Real estate' cost; Budget and construction time; Some other factors (etc.)

Practical implementation of the operation is two key phases: Research and Design. In the research stage, the authors developed methodical approach, taking into account experience of their foreign colleagues (USA, Canada, UK), as well as the basic principles of network centralization of the large private and organizations (Plotnikov V.A., Vertakova Yu.V. (2016)).

Based on the methodology of the value chain of $M$. Porter to optimize management system of the IFTS in its activities processes were grouped into a three groups:

-Main

-Auxiliary

-Service

Then Each group of processes were identified with processes which must be created in centralized DPS. Cabinet part of study also includes a comprehensive quantitative analysis of the statistics of the tax document from all regions of Russia in four types of documents for several years: accounting and tax reporting, required documents, registration documents, printing and mailing. To select the target regions, accommodate the new data center conducted a socio-economic analysis of the regions of the country with the use of correlation and regression analysis, and the $\mathrm{ABC}$ analysis. Created a list of key of regional and industrial indictors for benchmarking. The field part of the study included the diagnosis of three of five existing DPS in different cities of the country through personal interviews with key executives, the timing of the operations staff, as well as the personal inspection of manufacturing and warehouse space.

Environmental analysis was performed according to the method of choosing prospective region. To select a promising region for the creation of CMDI) was calculated the correlation coefficient of external factors of influence relatively to indicator "Volume of regulatory documents based on paper (by the number of sheets)."

The correlation coefficient - a measure that determines the extent of connection between motion/values of each represented factor with this exponent indicator. The correlation coefficient may be varied from « 1 » in case of positive correlation to «-1» at full negative. If the correlation coefficient is equal to $« 0 »$, variables are completely independent from each other.

Correlation analysis helps determine is it possible to predict the potential value of the indicator "Volume of regulatory documents", knowing the magnitude of external factors of influence. The calculation results are presented in the table below.

These data show that the greatest influence on the performance results of the FTS have 6 factors, including 4 factors of direct influence with relatively high value of the correlation coefficient (the number of companies and 
organizations, the number of small businesses, the population, the number of inspections) and 2 factors of indirect impact of lower influence (gross regional product, the number of post offices). Other factors can be considered as insignificant and largely derived from the most significant factors.

Table 1. Rating of influence of external factors on the correlation coefficient.

\begin{tabular}{|c|c|}
\hline Factors of influence & $\begin{array}{c}\text { Correlation } \\
\text { coefficient }\end{array}$ \\
\hline 1. $\begin{array}{l}\text { Number of enterprises and } \\
\text { organizations }\end{array}$ & 0,92 \\
\hline 2. Number of small businesses & 0,91 \\
\hline 3. Population & 0,90 \\
\hline 4. Number of IFTS & 0,87 \\
\hline 5. Gross regional product & 0,77 \\
\hline 6. Number of post-offices & 0,75 \\
\hline $\begin{array}{l}\text { 7. Population density, thou. pers. } \\
\text { on thou. sq. } \mathrm{m} \text {. }\end{array}$ & 0,24 \\
\hline $\begin{array}{l}\text { 8. The density of asphalted public } \\
\text { roads }\end{array}$ & 0,21 \\
\hline 9. The average wage of employees & 0,01 \\
\hline
\end{tabular}

The following is an analysis of the existence of the factor for the region and the ranking of regions according to the values of factors.

Analysis of the regions in the number of enterprises and small enterprises.

Allocation of the legal entities in the subject of the Russian Federation is given on basis of applications for the identification of economic entities, codes of Russian classifiers of technical, economic and social information, established in accordance with legislation in the field of technical regulations.

Full rating of Russian Federation' regions was carried out by:

The number of enterprises and organizations; The number of small businesses; The population; The population density; The GRP; The level of wages; The number of post-offices of RPS; The density of asphalted public roads; The natural indicators of IFTS; The performance indicators of IFTS; The external factors:

Analysis of regions by the external factors.

Analysis of regions on the external factors was carried out in the 3 different sections:

The amount of paperwork, mln. sheets (similar to the Analysis of the regions by natural indicators of the tax inspectorate);

The GRP (Gross Regional Product), mln. rubles;

The density of population thou. pers. on thou sq. $\mathrm{m}$.

Analysis of regions by the external factors is conducted to identify the most developed and populous regions with the highest volume of document processing. Borders of groups of regions in terms of volume and the external factors are listed in the table below.

The results of grouping regions by the $\mathrm{ABC}$-analysis method (Chetyrkin E.M., 2008) are listed on the graph below.

$\mathrm{ABC}$-analysis of regions by the external factors.
Table 2. Grouping regions by the ABC-analysis method.

\begin{tabular}{|l|c|c|c|}
\hline \multirow{2}{*}{$\begin{array}{l}\text { Grouping regions } \\
\text { by the ABC- } \\
\text { analysis method }\end{array}$} & $\mathbf{3}$ & $\mathbf{2}$ & $\mathbf{3}$ \\
\cline { 2 - 4 } & Group \\
\hline $\begin{array}{l}\text { Shares by the } \\
\text { indicator }\end{array}$ & Maximum & Average & Minimum \\
\hline $\begin{array}{l}\text { Volume of documents } \\
\text { to process, sheets }\end{array}$ & $\mathrm{A}$ & $\mathrm{B}$ & $\mathrm{C}$ \\
\hline $\begin{array}{l}\text { Gross regional } \\
\text { product, mln. rub. }\end{array}$ & $\mathrm{F}$ & $\mathrm{N}$ & $\mathrm{S}$ \\
\hline $\begin{array}{l}\text { Population density, } \\
\text { thou. pers. on thou. } \\
\text { sq. m. }\end{array}$ & $\mathrm{X}$ & $\mathrm{Y}$ & $\mathrm{Z}$ \\
\hline $\begin{array}{l}\text { Sum share by regions, } \\
\%\end{array}$ & $\begin{array}{l}\text { От } 0 \text { до } \\
50 \%\end{array}$ & $\begin{array}{l}\text { От } 51 \\
\text { до } 80 \%\end{array}$ & $\begin{array}{l}\text { От } 81 \text { до } \\
100 \%\end{array}$ \\
\hline
\end{tabular}

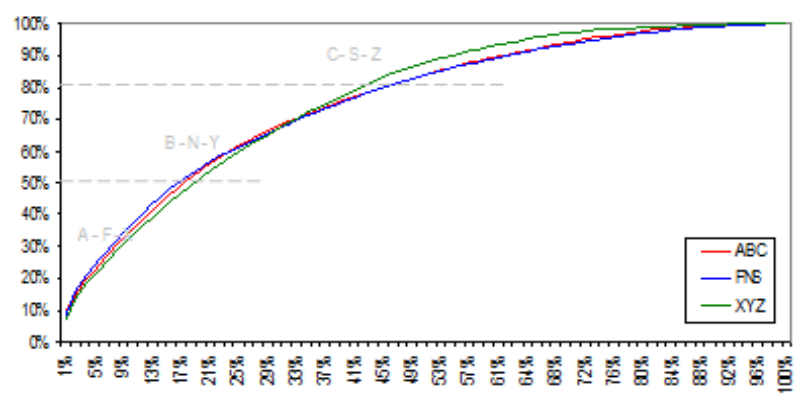

$A B C-$ Volume of documents processing, sheets.

FNS - Gross regional product, mln. D. (GRP)

$\mathrm{XYZ}$ - Density of population thou. pers. on thou sq. $\mathrm{m}$

Fig. 3. $A B C$-analysis of regions by the external factors.

The result of this variant of $\mathrm{ABC}$-analysis was developed a rating with IFTS with lead positions all 3 indicators. Table below.

Table 3. Rating of regions-leaders by the external factors.

\begin{tabular}{|c|c|c|c|c|}
\hline \multirow{2}{*}{$\begin{array}{l}\text { Rating of } \\
\text { regions- } \\
\text { leaders } \\
\text { by the } \\
\text { external } \\
\text { factors }\end{array}$} & \multicolumn{4}{|c|}{ Position } \\
\hline & 1 & 2 & 3 & 4 \\
\hline Region & $\begin{array}{l}\text { Moskovskaya } \\
\text { oblast }\end{array}$ & $\begin{array}{l}\text { Krasnodarsky } \\
\text { Krai }\end{array}$ & $\begin{array}{l}\text { Republic } \\
\text { of } \\
\text { Tatarstan }\end{array}$ & $\begin{array}{l}\text { Samarskaya } \\
\text { oblast }\end{array}$ \\
\hline $\begin{array}{l}\text { Volume of } \\
\text { documents } \\
\text { to process, } \\
\text { sheets }\end{array}$ & 43,3 & 14,8 & 14,5 & 12,4 \\
\hline $\begin{array}{l}\mathrm{ABC} \\
\text { group }\end{array}$ & A & A & A & A \\
\hline $\begin{array}{l}\text { Gross } \\
\text { regional } \\
\text { product, } \\
\text { mln. rub. }\end{array}$ & 1685 & 809 & 923 & 707 \\
\hline $\begin{array}{l}\text { FNS } \\
\text { group }\end{array}$ & $\mathrm{F}$ & $\mathrm{F}$ & $\mathrm{F}$ & $\mathrm{F}$ \\
\hline $\begin{array}{l}\text { Population } \\
\text { density, } \\
\text { thou. pers. } \\
\text { on thou. } \\
\text { sq. m. }\end{array}$ & 147 & 68 & 56 & 59 \\
\hline $\begin{array}{l}\mathrm{XYZ} \\
\text { group }\end{array}$ & $X$ & $X$ & $X$ & $X$ \\
\hline
\end{tabular}


From the aggregation of three leading figures of all 4 regions of the country. With total share of the volume of GRP processing not more than a $20 \%$ and an average population density of 83 people on $1 \mathrm{sq}$. $\mathrm{km}$. The low number of represented regions for these indicators. Due to the large proportion of the Moscow region. Particularly, it greatly overstates the average of the leading regions in the density of the population - more than 3 times compare to the average level, and other regions. Positioning of leading regions on the graph (image) below.

This positioning of the regions shows the absence of any clear tendency, however, forms separate segment of the developed regions with large amount of processing. At the same time, vast number of regions have both low population density and small GRP. The main factor affecting the value of these indicators is the uneven distribution of business activity centers (financial, production) in the country (Grechenyuk O.N., Grechenyuk A.V. (2014)). Taking into account the analysis of the factors compiled a list of the leading regions.

In the aggregate made ratings of Russian regions, the resulting analysis of the various factors of the macro environment, external and internal factors the IFTS activity, formed a list of 13 promising regions for the placement of CMDI.

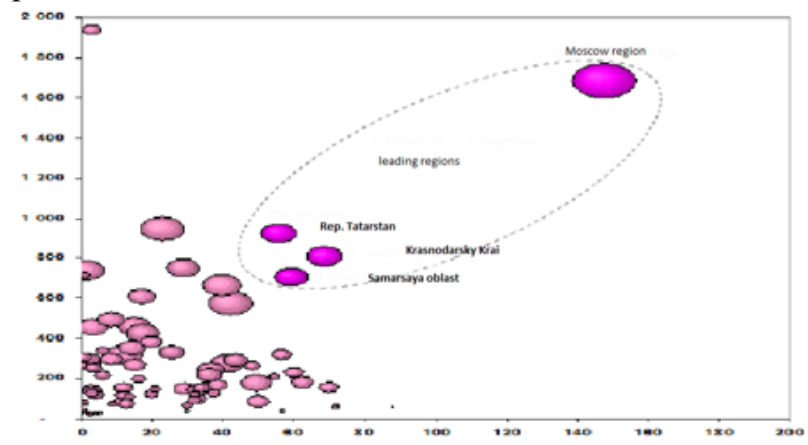

Fig. 4. Positioning of leading regions by the external factors (GRP and population density).

All these regions are leading for most indicators (Altai Krai, Voronezh Oblast, Krasnodar Oblast, Moscow region, Novosibirsk Oblast, Primorsky Krai, the Republic of Bashkortostan, Tatarstan, Rostov Oblast, Samara Oblast, Sverdlovsk Oblast, Stavropol, Chelyabinsk Oblast).

The territorial allocation of the leading regions forms a strongly marked axis of the adjacent densely populated areas of the South and the Black Sea regions through the industrial Ural region to Taimyr. Contact one of the leaders of the northern and Siberian regions due to peculiarity of their industrial development mainly in the mining industries. Also one of the leading positions took by Primorye region due to the high concentration of industry and business and population density.

Process of selection a perspective regions of Russia proved that by geographical location relative to each other and relative to other regions, not all of them can be earmarked for the formation of geographical clusters (William R. Kerr (2010)) and placing CMDI.
As shown at the figure above, regions suitable for dispositioning of CMDI can be divided into 3 groups:

Regions with existing CMDI, Target regions (without alternative), Alternative target regions. The composition of the target regions accommodation of the CMDI and 10 regional clusters is presented in the table below.

Table 4. Regions clusters.

\begin{tabular}{|c|c|c|}
\hline $\begin{array}{l}\text { Cluster \#1 } \\
\text { (center - Moscow) }\end{array}$ & $\begin{array}{l}\begin{array}{l}\text { Cluster \#2 } \\
\text { (center } \\
\text { Petersburg) }\end{array} \\
\end{array}$ & $\begin{array}{l}\text { Cluster \#3 } \\
\text { (center }-\quad \text { N. } \\
\text { Novgorod) }\end{array}$ \\
\hline $\begin{array}{l}\text { Regions: } \\
\text { Moscow }\end{array}$ & $\begin{array}{l}\text { Regions: } \\
\text { 1. Arkhangelsk region. } \\
\text { and Nenets } \\
\text { Autonomous District } \\
\text { 2. Vologda. } \\
\text { 3. St. Petersburg } \\
\text { 4. Kaliningrad oblast } \\
\text { 5. Leningrad region. } \\
\text { 6. Murmansk region. } \\
\text { 7. Novgorod region. } \\
\text { 8. Pskov region. } \\
\text { 9. Rep. Karelia } \\
\text { 10. Rep. Komi }\end{array}$ & $\begin{array}{l}\text { Regions: } \\
\text { 1. Kirov region. } \\
\text { 2. Nizhny Novgorod } \\
\text { region. } \\
\text { 3. Penza. } \\
\text { 4. Perm kr. } \\
\text { 5. Rep. Mari El } \\
\text { 6. Rep. Mordovia } \\
\text { 7. Ulyanovsk region. } \\
\text { 8. Chuvashia Rep. }\end{array}$ \\
\hline $\begin{array}{l}\text { Cluster \#4 } \\
\text { (center - Volgograd) }\end{array}$ & $\begin{array}{l}\text { Cluster \#5 } \\
\text { (center - Kemerovo) }\end{array}$ & $\begin{array}{l}\text { Cluster \#6 } \\
\text { (center - Dubna or } \\
\text { others.) }\end{array}$ \\
\hline $\begin{array}{l}\text { Regions: } \\
\text { 1. Astrakhan region. } \\
\text { 2. Volgograd region. } \\
\text { 3. Kabardino-Balkar } \\
\text { Rep. } \\
\text { 4.Karachay- } \\
\text { Cherkess Rep. } \\
\text { 5. Krasnodar kr. } \\
\text { 6. Rep. Adygea } \\
\text { 7. Rep. Dagestan } \\
\text { 8. Rep. Ingushetia } \\
\text { 9. Rep. Kalmykia } \\
\text { 10. Rep. North } \\
\text { Ossetia Alania } \\
\text { 11. Rostov region. } \\
\text { 12. Saratov region. } \\
\text { 13. Stavropol kr. } \\
\text { 14. Chechen Rep. }\end{array}$ & $\begin{array}{l}\text { Regions: } \\
\text { 1. Altai kr. } \\
\text { 2. Irkutsk region. } \\
\text { 3. Kemerovo region. } \\
\text { 4. Krasnoyarsk kr. } \\
\text { 5. Novosibirsk region. } \\
\text { 6. Omsk region. } \\
\text { 7. Rep. Altai } \\
\text { 8. Rep. Tyva } \\
\text { 9. Rep. Khakassia } \\
\text { 10. Tomsk region. }\end{array}$ & $\begin{array}{l}\text { Regions: } \\
\text { 1. Vladimir region. } \\
\text { 2. Ivanovo region. } \\
\text { 3. Kostroma region. } \\
\text { 4. Moscow region. } \\
\text { 5. Smolensk region. } \\
\text { 6. Tver region. } \\
\text { 7. Yaroslavl region. }\end{array}$ \\
\hline $\begin{array}{l}\text { Cluster \#7 } \\
\text { (center - Kaluga) }\end{array}$ & $\begin{array}{l}\text { Cluster \#8 } \\
\text { (center - Kazan) }\end{array}$ & $\begin{array}{l}\text { Cluster \#9 } \\
\text { (center } \\
\text { Ekaterinburg) }\end{array}$ \\
\hline $\begin{array}{l}\text { Regions: } \\
\text { 1. Belgorod region. } \\
\text { 2. Bryansk region. } \\
\text { 3. Voronezh region. } \\
\text { 4. Kaluga region. } \\
\text { 5. Kursk region. } \\
\text { 6. Lipetsk region. } \\
\text { 7. Orel. } \\
\text { 8. The Ryazan } \\
\text { region. } \\
\text { 9. Tambov region. } \\
\text { 10. Tula region. }\end{array}$ & $\begin{array}{l}\text { Regions: } \\
\text { 1. Orenburg region. } \\
\text { 2. Rep. Bashkortostan } \\
\text { 3. Rep. Tatarstan } \\
\text { 4. Samara region. } \\
\text { 5. Udmurtia. }\end{array}$ & $\begin{array}{l}\text { Regions: } \\
\text { 1. Kurgan region. } \\
\text { 2. Sverdlovsk region. } \\
\text { 3. Tumen. } \\
\text { 4. The Khanty- } \\
\text { Mansi Autonomous } \\
\text { Area - Yugra } \\
\text { 5. Chelyabinsk } \\
\text { region. } \\
6 \text {. The Yamalo- } \\
\text { Nenets Autonomous } \\
\text { county }\end{array}$ \\
\hline \multicolumn{3}{|c|}{$\begin{array}{c}\text { Cluster \#10 } \\
\text { (center - Khabarovsk) }\end{array}$} \\
\hline \multicolumn{3}{|c|}{$\begin{array}{c}\text { Regions: } \\
\text { 1. Amura. } \\
\text { 2. The Jewish Autonomous Region. } \\
\text { 3. Trans-Baikal kr. } \\
\text { 4. Kamchatka kr. } \\
\text { 5. Magadan region. } \\
\text { 6. Seaside kr. } \\
\text { 7. Rep. Buryatia } \\
\text { 8. Rep. Sakha (Yakutia) } \\
\text { 9. Sakhalin region. } \\
\text { 10. Khabarovsk kr. } \\
\text { 11. Chukotka Autonomous county }\end{array}$} \\
\hline
\end{tabular}


Source: Author's calculations

The number of regions in the cluster may be indicative to the scale of the administrative cooperation perspective, without being a characteristic of the bulk of the future performance of CMDI due to the uneven performance of regions.

As can be seen from the territorial distribution of the target regions of CMDI and regional clusters are not always able to avoid the adjacent location of the target region (see. The figure below). Among the areas of alternative locations of CMDI is recommended to choose: to cluster 8 - Kazan (Republic of Tatarstan); For 10 cluster - Khabarovsk (Khabarovsky Krai), due to a more central location of the city placing CMDI in the entire cluster.

The economic result:

As mentioned above, the centralization of mass data input and printing in CMDI will provide:

Centralization and creating of single database of the tax documents;

Reducing of the number of duplicated functions and data points;

Organization of the required level of quality and technological performance of the functions of mass entering and printing through the use of efficient equipment;

Increase the efficiency of processing incoming documents and notifications;

Redistribution of data-stream load, printing and sending out notices from IFTS employees to CMDI employees as a result liberation of human resources.

In terms of improving economic efficiency CMV creation solves the problem to reduce the unit cost of the notification by the following factors;

Reducing the cost of personnel performing the functions of mass entering and printing, while maintaining the scope of work (Yuya Kajikawa, Yoshiyuki Takeda, Ichiro Sakata, Katsumori Matsushima (2010));

Management of maintenance costs of printing by centralizing this type functions;

Assessment of the economic effects was carried out on the basis of the model developed CMDI activity for 5 years, which includes the production plan, organizational plan and spending plan by major economy CMDI. Modeling activities CMDI based on a combination of formal (mathematical) methods, expert assessments of experts and statistical data.

\section{Conclusions}

As a result, the preparation of the development strategy of the network of data centers Tax authorities made the calculation and comparison of options for implementing the functions of mass input and print documents. For each function carried out: the construction of an economic model functions, including two scenarios, and if necessary - embodiments of the function; calculation of the economy, which is achieved in the implementation of each of the scenarios and variants of the economic model in the target model management.

In accordance with international methodology of business planning UNIDO for the target model data centers are designed to create new plans for production and logistics, operations, financial and investment plan. These plans are defined reference values of key performance indicators in the data center of the economy, productivity and staff. Built target process model data center operations. The total cost savings over 5 years of the first scenario is 6871 million. rub. According to the second scenario - 11315 million. rubles.

This paper is an output of the science project of the government task government task of Ministry of Education and Science of the Russian Federation № 26.3546.2017/PCH "Development fundamentals of analysis and prediction of structural and dynamic parameters of the regional economy are based on the integration of the Russian and world experience of management of territorial development and modern scientific doctrines".

\section{References}

1. L.I. Askhatova, A.M. Fatkhiev, L.N. Safiullin, and A.M. Safiullina, Competitive Strategies (Sage Publications, London, 2000)

2. Federal State Statistics Service (Rosstat). http://www.gks.ru

3. Weber, Manfred, Business computing (Omega-L, Moscow, 2007)

4. E.M. Chetyrkin, Financial mathematics (Delo ANCH, Moscow, 2008)

5. William R. Kerr (2010) Journal of Urban Economics, 67, 1, 46-60 (2010)

6. V.G. Panskov, Economy Taxes. Right. Finance, 5, 130-138 (2016)

7. V.G. Panskov, Economy. Taxes. Right. Finance, 1, 114-120 (2015)

8. I.Y. Chugunov, O.M. Zhukevych, Economic Annals-XXI, 1-2(1), 61-64 (2014)

9. R.A. Musgrave, P.B. Musgrave, (Public Finance: Theory and Practice, 2009)

10. E.V. Balatsky, he Problems of forecasting, 2, 88-105 (2003)

11. L.I. Goncharenko, L.M. Arhiptseva, National interests priorities and safety, 6, 21-26 (2011)

12. I.A. Mayburov, Finance, 8, 45-49 (2012)

13. Yu. Vertakova, V. Plotnikov, Economical chasopisXXI, 156(1-2), 37-40 (2016)

14. V. Plotnikov, Y. Vertakova, Proceedings of the 26th International Business Information Management Association Conference - Innovation Management and Sustainable Economic Competitive Advantage: From Regional Development to Global Growth, 3224-3229 (2015) 
15. Y. Vertakova, Y. Polozhentseva, M. Klevtsova, Conference on Political Sciences Law, Finance Economics \& Tourism, 1, 399-406 (2014)

16. Y. Vertakova, Y. Polozhentseva, M. Klevtsova, E. Leontyev, Innovation management and education excellence vision 2020: from regional development sustainability to global economic growth, I-VI, 1134-1144 (2020)

17. Order Federal tax service, 2011 no. MMV-7-2/336 "On changing the composition and structure of the Handbook the Federal tax service of Russia "the Documents should be retained in electronic storage, as well as documents obtained by the tax authorities in the exercise of tax control" and the order of reference, approved by order FTS of Russia from 2009 and no. MM-7-2/517

18. N.E. Egorov, A.V. Babkin, G.S. Kovrov, S.V. Muraveva, Procedia - Social and Behavioral Sciences, 207, 816-823 (2015)

19. A.V. Babkin, V.S. Lipatnikov, S.V. Muraveva, Procedia - Social and Behavioral Sciences, 207, 749-758 (2015)

20. A.V. Babkin, S.V. Zdolnikova, Proceedings of The 28th International Business Information Management Association Conference, 1-11 (2016) 